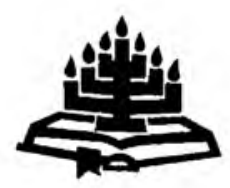

\title{
Die implikasies van enkele pneumatologlese inslgte van Rudolf Bohren vir die Praktiese Teologie
}

\author{
F.W. de Wet \& C.J.H. Venter \\ Skool vir Kerkwetenskappe \\ Potchefstroomse Universiteit vir $\mathrm{CHO}$ \\ POTCHEFSTROOM \\ E-pos:dmscjhv@puknet puk.ac.za
}

\begin{abstract}
The implications of a selection of Rudolf Bohren's pneumatological perspectives for Practical Theology

This article attempts to outline an approach to Practical Theology which will provide a new vision on the fullness and magnificence of the field of study. Possibilities in obtaining a new vision are illustrated by expounding three pneumatological perpectives on Practical Theology by the German theologian, Rudolf Bohren. By means of the analysis of and a conclusion drawn from Bohren's vision on a trinitarian-pneumatological approach, his application of the term teonomical reciprocity and his application of the aesthetical term, Wahrnehmung (perception), a unique and rich starting point for a vivid, spiritual approach to Practical Theology can be provided.
\end{abstract}

\section{Inleiding}

Die sentrale probleemstelling wat in dié artikel ter sprake kom, is die vraag of die huidige benaderingsmoontlikhede tot teologie in die algemeen en Praktiese Teologie in die besonder, 'n suiwer en onbegrensde visie verleen op die grootheid van die inhoud van hierdie vakgebied. Die kritiese vraag wat aan die eietydse prakties-teologiese wetenskapsbeoefening gestel word, is of dit die suiwer visie het op die taak wat voorhande is, sodat die vakinhoud tot sy heerlike en lewende volheid kan kom.

In aansluiting by hierdie probleemstelling wys die Duitse praktiese teoloog Rudolf Bohren (1975:16 e.v.) op 'n wesenlike gevaar vir wetenskapsbeoefening, naamlik dat dit in 'n verarmde denksisteem kan verval - 'n denksisteem waarin 
enige gedagte aan die skone uitgesluit word. Teologie kan tot 'n "ganz amusisches Gedankenleben" ingeperk word en kan gevange geneem word in 'n denksisteem waarin die Heilige Gees, as die Een wat alles nuut wil maak, verhinder word om lewend en krities teenwoordig te wees. 'n Geslote sisteem kan opgaan in die blote bevestiging van die bestaande. So 'n sisteem bewaar dan bloot, in plaas daarvan om ook ruimte vir vernuwing te skep: "Das ezechielische Rauschen in den Totengebeinen findet nicht statt" (Bohren, 1975:16).

Wat die verarming van Praktiese Teologie betref, het Jonker (1981:27) gewys op die moontlikheid dat 'n blote empiries-georiënteerde benadering tot die vakgebied die teologiese kwaliteit van Praktiese Teologie in gedrang kan bring. Die vakgebied kan sy teologiese gehalte verloor wanneer dit nie meer die openbaring van God tot voorwerp het nie, maar slegs die kerk as 'n empiriese en historiese grootheid. Die doelstelling van hierdie artikel is om verder te gaan en 'n nog dieper dimensie van faktore wat tot verarming in Praktiese Teologie aanleiding kan gee, te identifiseer. Al kan Praktiese Teologie hom verantwoord ten opsigte van die teologiese kwaliteit, die Skriftuurlikheid en wetenskaplikheid van die arbeid, loop dit nog steeds die gevaar om in 'n steriele, "amusische" denksisteem te verval. In so 'n denksisteem gaan die verwondering oor die grootheid van dit waarmee die wetenskaplike besig mag wees, verlore en die teorie kan gevolglik ook sy effektiewe werkingskrag verloor.

Om aan die doelstelling van die artikel vorm te gee, word by Bohren se pneumatologiese perspektiewe aangesluit met die vraag of hierdie perspektiewe 'n bydrae kan lewer om 'n verruimde en waarheidsgetroue visie op die taak en inhoud van Praktiese Teologie te bekom. Wanneer daar van verruiming en verlewendiging van denke sprake is, kan dit nie anders as om die denke te anker in 'n verantwoorde Pneumatologie nie.

Vir Daiber (1977:9) is Bohren se Praktiese Teologie niks anders as praktiese Pneumatologie nie. Die inhoud van die vakgebied bestaan dan in die werk van die Gees en die Woord in die kerk en deur die kerk.

Hierdie verwysing van Daiber kan dadelik die vermoede laat ontstaan dat Bohren se benadering sistematies-dogmaties gekleur mag wees. Al is die sistematiesteologiese benadering al met goeie reg gekritiseer omdat dit na bewering nie genoegsaam rekening hou met die empiriese faktore nie (vgl. Heitink, 1993:88), kan die benadering van Bohren tog van groot belang wees vir prakties-teologiese basisteorievorming. En dan moet Bohren se sogenaamde "dogmatiese" benadering boonop ook in perspektief gesien word. Josuttis (1996:10) toon besondere insig in die waarde van Bohren se benadering wanneer hy die volgende sê: "BOHREN vollzog damals keine defensive Abwehrhaltung aus einem theologischen Dogmatismus heraus; vielmehr wollte er die Freiheit des Predigt- 
geschehens gegen empirische Verengung bei seiner theoretischen und praktischen Wahrnehmung sichern".

Die belang daarvan om pneumatologiese faktore in ag te neem in praktiesteologiese denke is al goed deurgetrap in die arbeid van gereformeerde teoloe soos O. Noordmans, Th. Haitjema en A.A. van Ruler - teologiese besinning waarin aandag gevra is vir die werking van die Gees in die kerk en die wêreld nie alleen as voortsetting van die werk van Christus nie, maar ook as kritiese funksie ten aansien van die feitelike praxis (vgl. Dingemans, 1996:83). Ook in die Suid-Afrikaanse konteks is die belang van pneumatologiese faktore in praktiesteologiese denke goed deurdink: vergelyk byvoorbeeld Venter (1992:49) wat wys op die geheimenisvolheid van God se werk, wat meermale bo empiriese of teologiese ondersoek verhef is en Pieterse (1990:51) wat die plek van die Gees in 'n prakties-teologiese kommunikatiewe teorie as dié van 'n Brugbouer beskryf. Tog is die eie aksente wat deur Bohren gelê is van belang en kan dit tot nuwe perspektiewe lei. In sy ryk geskakeerde pneumatologiese benadering wil ons vir die doeleindes van hierdie artikel slegs drie perspektiewe belig, naamlik die Pneumatologie in trinitariese raamwerk, die verhouding tussen die goddelike en menslike wat deur 'n teonome resiproke verhouding gekenmerk word en die verruimde waarnemingsmoontlikhede wat vir 'n Geesvervulde gelowige oopgaan.

\section{Rudolf Bohren se pneumatologiese perspektiewe}

\subsection{Pneumatologie in trinitariese raamwerk}

Vir Bohren is die triniteitsleer sentraal in sy prakties-teologiese denke: die teorie van die praxis van God kan alleen in die raamwerk van die triniteitsleer vasgestel word. Praktiese teologie bestaan wesenlik daarin dat dit praxis vanuit God met betrekking op God reflekteer; dat dit die prakties-wordende God reflekteer:

den Gott also, der in seinem Aus-Sein auf neue Horizonte sich von Gott unterscheidet, der sich selbst von neuen Horizonten neu bestimmen laßt und uns durch sein Anwesen neu bestimmt; den Gott also, der als Schöpfer praktisch wird und im Sohn und beidemal durch den Geist, sei es als 'ruach elohim' oder als 'pneuma Christou' (Bohren, 1975:45).

In Bohren se benadering vanuit die triniteitsleer vind sy denke 'n definitiewe vertrekpunt vanuit die pneumatologiese kategorie. Solank daar nog so 'n kerk op aarde is en ons nog nie op die nuwe aarde woon nie, word God vir ons op geen ander manier prakties as deur sy Gees nie. Die tyd tussen die tye is die tyd van die Gees, die tyd, waarin God uit Homself uittree - "außer sich ist, auf neue Horizonte" (Bohren, 1975:45). Bohren se Pneumatologie word gebore in die teologiese denkklimaat van die sestigerjare waarin die primaat van die Christologie en die klem op die historiese Jesus alle bewussyn van die Heilige Gees verdring het (Daecke, 1975:520). Die probleem wat Bohren het met die 
manier waarop teologie tradisioneel ingedeel word (volgens die skema: Eksegese, Kerkgeskiedenis, Sistematiek, Praktiese Teologie) is dat dit metodologies uitgaan van God wat was - en God wat is en God wat kom, buite rekening laat (Bohren, 1975:45 e.v.; vgl. Bohren, 1965:89).

Wanneer Christus nie binne die raam van die triniteitsleer beskou word nie, word die menswording van Christus geïsoleerd (histories) beskou en word daar nie voldoende rekening gehou met wat die woorde oor Christus (Bybelse teks) sedert hulle teboekstelling tot op die huidige vermag het nie. Die historiese Christus kan die lewende Christus wat deur sy Gees teenwoordig is, bedek. Die lewendigwees van Christus word nie genoeg gereflekteer wanneer dit nie in verband met die lewendig-wees van die Vader en die lewendig-wees van die Gees verbind word nie (Bohren, 1975:47 e.v.). Binne die trinitariese struktuur funksioneer die Gees as die Een wat die verlede lewendig maak in die hede en wat die toekoms antisipeer (Bohren, 1965:90).

Wir werden den Christus praesens nicht recht predigen, wenn wir nicht paradigmatisch $2 u$ sagen wissen, was er tut. Verzichten wir mit dem Hinweis auf die Verborgenheit Gottes auf neue Paradigmen, so verzichten wir im Grunde auf die Predigt des Auferstandenen und im Pneuma Gegenwartigen und Wirkenden; Wir historisieren die Heilsgeschichte (Bohren, 1967:353).

Die Gees moet in die denke van Bohren egter nie van Christus geïsoleer word nie. Christus kom as Wegbereider van die Gees en die Gees kom as Openbaarder van Christus (Bohren, 1981b:9). Die Gees, as die ander Trooster, voer die werk van Jesus verder. Hy sê die "noch-Ungesagte" en doen die "noch-Ungetane". Die Heilige Gees "zieht uns hinein in die neue Welt Gottes, öffnet uns die Augen für Gott, der Vater, neue Augen für Gott, der Sohn, neue Augen auch fur diese Erde, die seine gute Schöpfung ist, neue Augen auch für die Gemeindem die seine neue Schöpfung ist" (Bohren, 1981a:145).

As 'n nadere omlyning van die funksie van die pneumatologiese denke ten opsigte van die Christologie, stel Bohren (1981b:16) dat dit die Christologie in die "Fleisch der Gegenwart" invoer. In die Gees leef die mens nie bloot tussen die tye nie, maar deur die Gees word verlede en toekoms in die huidige teenwoordigheid geïntegreer. Die Christen leef dus nie net ná Christus nie, maar ook met (in) die geboorte van Christus in 'n nuwe syn, in samehang met sy lyding, vernedering en verhoging.

Met kritiek as denkkriterium wil die pneumatologiese denke nie die Christologiese denke in die skaduwee stel nie, maar dit in die regte lig plaas. Pneumatologiese denke kan 'n belangrike rol speel in die kritiese deurdringing van alle wetenskap. Dit kan beslis krities funksioneer ten opsigte van 'n verengde Christologiese denke. As voorbeeld van die wyse waarop pneumatologiese denke krities ten opsigte van Christologiese denke funksioneer, verwys Bohren 
(1981b:11) na die huidige kenmerk van die Westerse kultuur waarin tegniek en natuurwetenskap 'n oorheersende rol speel as die moontlike afvalproduk van verengde Christologiese denke - 'n denke waarin net oor God en die siel gedink word, 'n denke wat van die Verlosser en Voleinder van die skepping vergeet het.

Bohren se vertrekpunt in die pneumatogiese kategorie laat Cilliers (1979:179) tot die gevolgtrekking kom dat Bohren in navolging van Van Ruler die verhouding tussen Christus en die Gees nie volkome deurdink het nie. Die Gees bly merendeels die Gees van die Vader en die Filioque word nie gehonoreer nie (vgl. Hasselmann, 1977:120). In ooreenstemming hiermee meen Grözinger (1989:27) dat Bohren met sy pneumatologiese begronding van die praktiese teologie die gevaar loop om eksklusief pneumatologies te dink en sodoende die trinitariese vertrekpunt op die agtergrond te laat verdwyn. Teenoor kritiek soos dié van Cilliers en Grözinger moet egter in gedagte gehou word dat Bohren in navolging van Van Ruler juis rekening hou met die struktuurverskille tussen Pneumatologie en Christologie sonder om uit die oog te verloor dat die Gees nie alleen van die Vader uitgaan nie, maar ook van die Seun. Die pneumatologiese struktuur waarin dit gaan oor God in ons, leen hom beter tot die bestudering van die praktiesteologiese vakgebied as 'n suiwer Christologiese struktuur waarin die God-inChristus-verhouding die oorwegende is (vgl. Van Ruler, 1969:176). Bohren se vertrekpunt vanuit die pneumatologiese struktuur bly in sy diepste wese dus trinitaries. Sy denke is in der waarheid trinitaries-pneumatologies. Wat die pneumatologiese struktuur betref, wys Berkhof (1964:20) daarop dat dit moontlik is en selfs voor die hand liggend is om die Christologie vanuit 'n pneumatologiese gesigspunt te benader. Die Gees rus op Jesus en die Gees gaan uit van Jesus. Die persoon en werk van Jesus Christus word dan beskou as die resultaat, die beginpunt en middelpunt van God se leweskenkende aanwesigheid van die werk van die Gees onder die mense.

Om nou by die prakties-teologiese implikasies van die benadering vanuit 'n pneumatologiese kategorie uit te kom: by Thurneyssen leer Bohren om teologie as dinamies en as voortgaande beweging te sien (Theologie, die fortgehen will). Hierdie perspektief van Thurneyssen lei Bohren om teologie te sien as teologie in die voortbeweeg van genade, 'n teologie waarin God mooi word (Gottes schön werden) en mooi wil word, teologie waarin die heil geskiedenis maak; teologie wat ons dus nog nie ken nie (Bohren, 1979:9). Bohren se pneumatologiese perspektief in samehang met die voortganggedagte van Thumeyssen gee aan sy teologie 'n dinamiese, beweeglike element wat dit deur niks in 'n geslotenheid laat vasvang nie. Hierdie klem op die beweeglikheid en onafgeslotenheid kan seker tot 'n groot mate terugherlei word na die dialektiese teologie van Karl Barth waarin die verhewenheid en vryheid van God sterk beklemtoon word. Wanneer Barth se Skrifbeskouing met die beweeglikheid en vryheid in Bohren se pneumatologiese denke vergelyk word, is die paralelle duidelik: vir Barth is die 
Skrif slegs Woord van God in soverre die Skrif deur die Gees op 'n bepaalde moment gebruik word vir sy diens. God kan egter nie van sy vryheid beroof word deurdat sy vrye, soewereine openbaring gestabiliseer word in 'n vaste, grypbare werklikheid waaroor ons, mense, kan beskik nie (vgl. Heyns, 1955:26; Schulze, 1981:73 e.v.). Maar al mag hierdie klem op beweeglikheid sy wortels in dialektiese teologie hê, moet ook in gedagte gehou word dat dit ook konsekwent voortvloei uit die triniteitsleer. Om dit in die woorde van Grözinger (1989:11) te stel: "Die Trinitätslehre ist die unerläßliche, aber auch unerläßliche schwierige Ausdruck der einfache Wahrheit, daß Gott lebt. Wer lebt, der ist in Bewegung (kursivering - FWdeW/CJHV), der hat Geschichte" (vgl. Grözinger, 1995:48).

Hierdie klem op beweeglikheid en onafgeslotenheid het uit die aard van die saak verreikende gevolge vir die inrigting van prakties-teologiese denke. So 'n benadering tot die vakgebied bring die praktiese teoloog tot die besef van sy eie nederigheid wanneer hy met die betreklikheid van sy arbeid en van sy beheersing van die vakgebied rekening hou. Omdat die praktiese teoloog wat sy vertrekpunt vanuit die pneumatologiese kategorie neem, ook besef dat sy navorsingsterrein nie verteenwoordigend is van 'n geslote sisteem nie, sal hy altyd die verwondering kan behou oor die altyd nuwe perspektiewe wat oopgaan. Terminologie soos groei, mooi-word, verwondering sal die sleutelterminologie word wat die gang en aard van die prakties-teologiese wetenskapsbeoefening (sal) bepaal.

\subsection{Teonome resiprositeit}

Wanneer dit by die verhouding tussen God en mens in die prakties-word van God kom (wat op grond van die aard van die karakter van die vakgebied ook 'n belangrike vraag vir die Praktiese Teologie is), vra Bohren (1975:67) 'n baie belangrike vraag:

Wird Gott in unserer Praxis praktisch, oder machen wir uns den Gott, den wir praktisch brauchen? Es ist deutlich, daß wir dann je nach unserer Praxis, je nach unseren Bedürfnissen eine Vielzahl von Gottern brauchen, auch wenn wir die Vielzahl monoton benennen.

God word dan prakties daarin dat die mens Hom prakties maak. Dan maak die mens 'n God wat hy kan gebruik.

Vanuit 'n ander invalshoek kan die verhouding tussen die Goddelike en die menslike in die prakties-word van God ook op die eenmalige menswording (in Christus) fokus en die praxis van die kerk en die Christendom beskou vanuit 'n refleksie op hierdie eenmalige praxis. Die mens het ook dan niks meer te doen nie, terwyl God alles vir die mens doen (Bohren, 1975:68). Die mens is 'n sondaar en volstrek afhanklik van God en daarom nie in staat om self iets te doen nie. Hoogstens word mense as ampsdraers geheel en al instrumente in God se hand. Dit lei tot ' $n$ teenstelling tussen ampsdraers wat as werktuie van God met 
gesag spreek van Christus, en die gemeentelede of leke wat geroep is om te luister en te gehoorsaam (vgl. Dingemans, 1996:84).

Teenoor hierdie verkeerde persepsies oor die verhouding tussen die Goddelike en die menslike in die prakties-word van God (waarin aan die een kant aan die menslike te veel mag toegeken word en aan die ander kant die menslike aksieloos gemaak word), vra Bohren hoe die Goddelike en menslike in balans kan kom. In hierdie poging om balans te bring, maak hy gebruik van 'n term waarin hy die afbuigende liefde van God wil omskryf, naamlik Verkleinerung. Die toenemende Verkleinerung Gottes is tegelykertyd 'n toenemende vermensliking. In Jesus word God mens, word Hy in 'n mens prakties. So tree die Johannese Christus as die Voleindiger van die werk van sy Vader na vore. Hy leef vir hierdie werksvoleinding: "My voedsel is om die wil te doen van Hom wat My gestuur het en om sy werk te voltooi" (Joh. 4:34; Bohren, 1975:68).

In sy soeke na 'n juiste omlyning van die verhouding tussen die Goddelike en menslike sluit Bohren (1993:76) dan kennelik aan by 'n begrip wat deur Van Ruler ontwerp is, naamlik teonome resiprositeit (Van Ruler, 1969:181; vgl. Dingemans, 1996:82). In Bohren se prakties-teologiese denke word teonome resiprositeit dan 'n sleutelbegrip, wat as 'n hermeneutiese prinsipe dien in die verstaan van handelinge in die kerk (vgl. Heitink, 1993:88). Die grondvraag van die praktiese teologie is vir Bohren die vraag na die prakties-word van God. Nader omlyn, is dit vir hom die vraag na teonome resiprositeit. Die vraag na die kerklike praxis word daarmee 'n vraag na die prakties-word van God in ons en deur ons. Die vraag na die kerklike praxis is die vraag na die ooreenstemming of divergensie van God se handelinge en ons handelinge (Bohren, 1979:13). Teonome resiprositeit laat rekening hou met die werklikheid dat God via mense en binne strukture in ons werklikheid werk. Agter die skerms van die lewe is God self aan die werk deur sy Gees. In 'n intense samewerking met mense en magte werk God om ons sondige en geskonde wêreld in sy oorspronklike skeppingsbedoeling te herstel (vgl. Dingemans, 1996:84).

Aangesien teonome resiprositeit 'n sleutelbegrip in die pneumatologiese denke van Bohren is, sou dit goed wees om vas te stel hoe Bohren die begrip teonome resiprositeit definieer.

Die aard van die verhouding tussen die Goddelike en die menslike word as teonoom getipeer: "Theonom heißt hier: die Praxis is wortbestimmt (met verwysing na die blinde by Siloam - deurdat Jesus 'n woord spreek, word die blinde tot uitvoerende orgaan van die woord) und das Personalpronomen wechselt immerzu (Jesus knie die klei met die oog op die blinde, die blinde reageer op grond van die woord van Jesus) (Bohren, 1975:70). Teonoom staan teenoor outonoom. Die Here is altyd die een wat die praxis inisieer. Die mens word meegevoer in die werk van God. 
Onder resiprositeit verstaan Bohren samewerking tussen God en mens. In die "Miteinander" van God en die mens word God prakties (Bohren, 1975:71). Terwyl die aard van die verhouding tussen God en mens as teonoom omskryf word, word die interaktiewe wisselwerking in die verhouding met die woord as resiprositeit getipeer. Die resiproke bestaan daarin dat die Goddelike en menslike nie as twee teenstellende groothede gesien word nie, selfs nie as losstaande nie, maar in noue samewerking. God werk nie alleen in ons nie, maar eintlik ook altyd saam met ons (Bohren, 1993:76; vgl. Jooste, 1986:15). Met hierdie omskrywing van resiprositeit vind Bohren sterk aansluiting by Van Ruler. Vir Van Ruler lê die kern van resiprositeit daarin dat die mens ook tot die Middelaar wat in sy plek staan, in 'n verhouding van resiprositeit te staan kom. Die mens laat hom vervang; hy laat die Middelaar in sy plek staan. Vanuit die resiprositeit kan daar vanuit 'n bevindelike invalshoek vir die Middelaar ook "my Middelaar" gesê word. Versoening kan daarom nie alleen vanuit Christologiese oogpunt gesien word nie, maar daar moet ook met die pneumatologiese gesigspunt rekening gehou word. Dit is nie genoeg dat Jesus Christus vir my op Golgota gesterf het nie, maar ek self moet daarmee hier en nou eens wees om Hom vir my gestorwe te laat wees en om sy offer te aanvaar (Van Ruler, 1969:181; vgl. Van Ruler, 1978:26). Hierdie betrekking tot die Middelaar sorg dat die verhouding tussen die Gees van God en die gees van die mens nie opgaan in subjektiwisme, waarin die Gees bloot die bewerker van die mens se innerlike Godsbewussyn en die vormer van sy religieuse persoonlikheid word nie (vgl. Jonker, 1983:91).

Terwyl die pneumatologiese denke van Bohren aan die orde is, volg die vraag hoe die Heilige Gees betrek word by teonome resiprositeit. Terwyl die middelaarskap van Christus in plekomruiling bestaan, werk die Gees nie alleen in ons en aan ons nie, maar ook altyd met ons in die sin van tesame met ons (zusammen mit uns). Hy betrek ons by sy handelinge. Hy aktiveer ons, deurdat Hy aktief is.

\begin{abstract}
Was in der Christologie Stellvertretung heißt, heißt in der Pneumatologie Reziprozitat Theonome Reziprozität .... das Kennzeichnende des Werkes des Geistes ist, daß er uns ans Werk setzt. Gott wird im Geist zum Genossen des Menschen, und der Mensch wird zum Genossen Gottes In dieser Genossenschaft bleibt Gott Gott und der Mensch Mensch. Aber beide sind unterwegs, und der Mensch wird hier durchaus zum Partner, ohne dessen Mitwirkung kommt es nicht zur Veranderung. Theonome Reziprozitat is der Wechsel vom 'ich' zum 'wir' (Bohren, 1993:76).
\end{abstract}

Die werk van Heilige Gees bestaan juis daarin dat Hy die mens weer volledig opneem en inskakel (vgl. Jooste, 1986:12). Rothermundt (1984:36) meen dat daar kennis geneem moet word van die implikasies van hierdie pneumatologiese insigte van Bohren, omdat dit die ervaarbaarheid van die Gees, maar ook tegelykertyd die feit dat daar nie vrylik oor die Gees beskik kan word nie, ewe sterk beklemtoon en in die sleutelbegrip teonome resiprositeit in betrekking met mekaar plaas. 
Omdat teonome resiprositeit by Bohren 'n baie ryk begrip is en op ' $n$ intensiewe wyse verder omlyn word, kan dit vir die doeleindes van die artikel nodig wees om aan enkele aspekte van Bohren se verdere omlyning van hierdie begrip aandag te gee. In 'n nadere omlyning van die resiproke verhouding tussen God en mens sê Bohren (1975:71) dat God Hom afhanklik maak van die mens. Maar hierdie afhanklik-wees van die mens impliseer nie 'n versaking van die almag van God nie. Hierdie afhanklik-wees impliseer 'n aangewese wees op die mens in liefde. Die Heilige Gees is die Gees van liefde. Liefdeloosheid het die ander nie nodig nie. Tot die wese van liefde hoort die volgende implikasie: wie liefhet, het die ander nodig, verlang na die ander een, kan - om dit so uit te druk - niks doen sonder die ander een nie. Bohren (1975:72) gaan verder en sê dat dit nie alleen die menslike handeling is wat woord-bestemd is nie, maar ook die Goddelike handeling. God handel in Jesus nie willekeurig nie. Jesus het gehandel omdat sy dissipels Hom op die blindgeborene gewys het. As genoot van die mens handel God vanaf sy kant antroponoom. Terwyl God ook in sulke handelinge God bly, behoort die gebed 'n leidende plek te hê as tema van praktiese teologie en as aktwiwiteit waarin die kerklike praxis opgaan: "Praktische Theologie hat nicht das Handeln von unerhörten Menschen zu behandeln, sondern das Handeln von Erhörten, von Menschen, auf die er hört, die auf ihn hören, denen er 'hörig' wird, weil sie ihm gehören."

As 'n verdere karakterisering van die teonoom-resiproke verhouding stel Bohren (1975:74) dat die gedagte van "Verkleinerung" van God in die Gees met die gedagte van resiprositeit verbind moet word:

Gott verkleinert sich, um des Menschen Genossen zu werden, Hausgenosse des unbehausten Menschen, indem er diesem einwohnt. Er verkleinert sich, um den Menschen groß zu machen, eben zu seinem Genossen. Er bestimmt den Menschen zum Beter, um ihn, Gott selbst, zu bestimmen (vgl. Jes. 62:6 e.v.).

Die vraag ontstaan of Bohren nie hier die ewige, onveranderlike raad van God in gedrang bring nie. Tog is die gebede van gelowiges op 'n onverklaarbare wyse in die ewige raad van God opgeneem en het dit groot krag (vgl. Jak. 5:16).

Om die waarde van Bohren se omlyning van die verhouding tussen die Gees van God en die gees van die mens as 'n verhouding wat deur teonome resiprositeit gekenmerk word, in perspektief te stel, kan verwys word na ander pogings om hierdie verhouding te tipeer: Hoenderdaal (1968:87) verwys na 'n aanhaling uit H. Wheeler Robinson se boek The Christian experience of the Holy Spirit:

The revelation of Spirit in human personality consists in an experience of fellowship with God, whether the experienced values are moral, intellectual or aesthetic In this fellowship we can never hope to analyze exactly the human and divine contribution; genuine religious experience springs from the most intimate and subtle blending. 
Na aanleiding van hierdie woorde sê Hoenderdaal dat Robinson nadruk op twee dinge lê wat baie belangrik is: die werking van die Gees het naas die etiese ook te doen met die intellektuele en estetiese aktiwiteit van die mens en tweedens: die samewerking van God se Gees en die mens se gees bly 'n onoplosbare misterie (kursivering - F.W. de W.).

Bavinck (s.j.: 72) druk die samewerking tussen die Goddelike Gees en die menslike gees ook op 'n vae en onomlynde wyse uit wanneer hy sê: "Hy doet en wij doen. Hij is bezig met ons en wij zijn bezig met Hem. En de twee grijpen op elkander in".

Om van 'n onoplosbare misterie te praat kan egter onbevredigend wees en hou nie rekening daarmee dat die samewerking tussen die Goddelike Gees en die menslike gees tog nader omlyn kan word nie. Van Ruler en Bohren se omlyning van hierdie samewerking deur middel van teonome resiprositeit is verhelderend. In hierdie omlyning word daarmee rekening gehou dat die Gees die oorheersende is, maar op so 'n wyse dat dit nie met 'n onderdrukking van die menslike gees gepaard gaan nie. Die teonoom-resiproke bestaan in die werking van 'n nuwe lewe wat die menslike gees in 'n duursame wisselwerking met die Heilige Gees plaas (vgl. Jooste, 1986:39).

Wat sou die prakties-teologiese implikasies van teonome resiprositeit wees? Bohren (1975:75) meen dat die gedagte van teonome resiprositeit bevrydend kan werk in ' $n$ tyd waarin minderwaardigheidsgevoel Christene regeer. Die geskiedenis van Josef (Matteus 2:13-15) is 'n bewys dat 'n onbeduidende persoon, in teonome resiprositeit tot 'n potens word. In die moment waarin die engel in 'n droom aan Josef verskyn, hang die hele heilsgeskiedenis van die wêreld af van iemand wat andersins geen rol sou speel nie. Die funksieloosheid van soveel individuele Christene in die gemeente-opset sou ook opgehef kon word waar teonome resiprositeit prakties word:

Und sie (Theonome Reziprozitat) wird da praktisch, wo der Heilige Geist nicht nur
auf den Weg schickt, wo vielmehr unterwegs ein Wort das andere gibt: Theonome
Reziprozitat setzt einen theonomen Dialog voraus, ein genossenschaftliches
Gesprach, das Gott in alten Bund eroffnet hat und das er im neuen Bund forsetzt,
ein Gesprach, in dem der Geist in alle Wahrheit fuhrt - in solchem Gespräch soll
auch die Bitte des Psalmisten zu ihrem Ziel kommen, zur Freude an Jahwes Hilfe
und zum bereitwilligen Geist. Diese Gespräch ist heute in der Kirche zu führen,
und Praktische Theologie ist in diesem Betracht nicht anders als die Einführung in
dieses Gespräch, in seine Planung und Durchfuhrung

'n Verdere prakties-teologiese implikasie van die toepassing van teonome resiprositeit vir die praktiese situasie in die kerk is dat dit ' $n$ nuwe perspektief bring vir die dilemma van die dienaar in die koninkryk van God wat sy eie nietigheid besef in kontras met die grootheid van die Woord van God. Die 
dilemma bestaan in die uiterste begrensdheid van die menslike vermoë en insig teenoor die Woord van die oneindig verhewe Here. Indien die dilemma van Barth tussen die "Von-Gott-reden-sollen" und "Nicht-Können" (vgl. Bohren, 1993:33) 'n egte dilemma daarstel, sou die begrip teonome resiprositeit 'n uitweg kon aandui deurdat aan God die eer gegee word en die mens se "Tun" 'n waardigheid kry. Die begrip teonome resiprositeit sou daarom ook 'n sleutel kon bied om die est van die baie bekende Reformatoriese formule "die prediking van die Woord van God is die Woord van God" te interpreteer (Bohren, 1975:76). Volgens Cilliers (1979:212) het Bohren se definiëring van die teonome resiprositeit en die waardigheid wat daarin aan die mens se optrede verleen word, verreikende implikasies vir die uitbou van 'n gereformeerde visie op die Heilige Gees se werking in die prediking. Die Heilige Gees is die Een wat die wonderbare ("wie is daartoe in staat?") en die maakbare ("hoe is ek hiertoe in staat?") in die prediking in balans bring.

\subsection{Geloof en waarneming}

'n Volgende sleutelkenmerk van die pneumatologiese denke van Bohren is die nuwe waarnemingsmoontlikhede wat deur die geloof oopgemaak kan word. Bohren (1996:79) sluit aan by 'n stelling van Gregorius van Nyssa: "Immer ist schöner das Je-neu-Gefundene als das schon Begriffene". Hy laat hom lei deur Calvyn se uitleg van 2 Korintiërs 4:18 om die oë van die geloof te sien as 'n waamemingsintuig wat verder dring as die natuurlike sinne (vgl. Calvyn, 1976: 65). Die primêre sig het sy wese in die aanskoue van die onsigbare en word vervul met verwondering oor die "Je-neu-Gefundene". Hierdie sig kom nie neer op menslike sienvermoè nie, maar bestaan in 'n waarnemingskerpte wat alleen verleen kan word deur die Een wat ons toegerus het om dienaars van die nuwe verbond te word, nie van die letter nie, maar van die Gees (vgl. Rom. 7:6). Wie tot diens van die nuwe verbond toegerus word, kry nuwe oe, wat verder dring as enige ander optiek. Hy sien alles deur nuwe oê en word vervul met verwondering oor wat hy sien.

Geloof is vir Bohren (1989:2) by uitstek 'n estetiese fenomeen, insoverre God self deur die geloof waargeneem word in sy mooi-word in die skepping, kuns, kultuur, geskiedens en die gemeente. Bohren verstaan Estetika as "eine Art und weise theologischen Erkennens" (vgl. Bohren, 1975:125). Bohren omskryf hierdie "theologische Erkennen" met behulp van Max Bense en Abraham Moles se informasie-estetika (wat hy as "Wegzeichen" en nie as "Wegweiser" nie gebruik) as 'n waamemingsproses wat nie alleen semantiese informasie verwerk nie, maar ook estetiese informasie. Hierdie onderskeid tussen semantiese en estetiese informasie kan geplaas word in 'n kategorie wat in die teologie reeds lank bekend is, naamlik die onderskeid tussen letter en Gees. Teologie kan nie net bly by semantiese informasie nie, maar moet voortgaan om die mooi-word van God 
waar te neem, in sy Novum soos dit in die gemeente as nuwe werksaam is (Bohren, 1975:128). (Vgl. Giannaras, 1974:19-22 vir 'n volledige bespreking van die informasie-estetika.) Dit is juis ook opvallend dat Jesus die teoloe van sy tyd gekritiseer het omdat hulle nie die nuwe van die komende Godsheerskappy waargeneem het nie. Hulle het goed geweet wat die verlede gesê het (semantiese informasie - FWdeW/CJHV), maar het egter nie geweet wat die hede nodig het nie; daarom was hulle blinde leiers van blindes (Matt. 15:14; Bohren, 1994:256).

Geloof het egter nie net te doen met die waameming (sien) van die mooie waartoe God die gemeente vernuwe het nie, maar het ook te doen met waameming in die sin dat die geleentheid waargeneem word om aktief die mooie van die kerk aan te moedig en te sorg dat dit altyd nuut bly. "Praktische Theologie als theologische Ästhetik sorgt sich darum daß die Kirche neu und also Kirche sei" (Bohren, 1975:130). Met hierdie dubbele omlyning van die waamemingsbegrip lewer Bohren 'n bydrae wat van groot waarde kan wees vir die definiëring van die teorie-praxis-verhouding, wat nog altyd een van die groot probleme van prakties-teologiese wetenskapsbeoefening was:

In der Doppeldeutigkeit Erkennen und Tun des einen Begriffes 'Wahrnehmen' liegt die Einheit von Theorie und Praxis. Das Wahrnehmen ist schon Aktion, leitet uber zur Aktion. In diesem Sinne bildet das Wahrnehmen das primare Problem Praktischer Theologie ..." (Bohren, 1975: 135).

Die prakties-teologiese konsekwensies van die waarnemingsbegrip is verreikend. As voorbeeld van die verreikendheid van hierdie begrip in pneumatologiese konteks vir die "hier-en-nou"-situasie van die kerk, kan verwys word na Bohren (1981b:20 e.v) se beskouing oor "gerichtetes Denken". Die probleem waarin die teoloog se waarneming kan verval, is dat sy denke en waarnemings blind is vir wat God vandag met mense doen. Sy oë neem nie waar wat die Gees waarneem nie. Dan neem hy nie waar dat die tydsverskynsels daarmee te doen het dat die wêreld in 'n uur van gerig verkeer nie. Pneumatologiese denke is by uitstek kritiese denke, in soverre die waarnemer homself, sy kerk, sy leefwêreld midde in die gerig van God waarneem. (Met gerig bedoel Bohren die geregtigheid wat deur God tot stand gebring word. Gerig (krisis) bring genade vir diegene wat genade nodig het en verlies vir diegene wat te veel het.)

Pneumatologiese denke sal die gerig nie kan waarneem wanneer dit nie toelaat dat die eie denke ook deur die gerig gaan nie. Pneumatologiese denke is 'n denke wat gevul is deur die vrees van die Here. Die vrees van die Here maak 'n nuwe dimensie van waarneming oop (Bohren, 1981b:23). Denke wat deur die gerig gaan, is ook denke waarin daar 'n element van lyding is. Die belofte van die Gees maak die gebrek aan die volle teenwoordigheid van die Gees 'n pynlike bewuswording. Pneumatologiese denke smag met die versmagting van die Gees, 
en die Gees vang die toon wat Jesus in sy lyding opgeneem het op. In Romeine 8:15 gebruik Paulus dieselfde werkwoord wat die evangeliste (Markus 15:13 e.v.; Matteus 27:50) vir Jesus se roep aan die kruis gebruik het. (Die Gees van Seunskap is 'n Gees van lyding met Christus en lyding vanweè die tyd.) Die mens het nog nie sy doel bereik nie. Die wonde van die nog-nie is van die begin af op die weg van pneumatologiese denke gelê. Aan die riviere van Babilon het die volk van God hulle klaende heimweelied gesing en die martelare onder die altaar vra: Hoe lank nog heilige en waaragtige Here, vergeld $U$ ons bloed nie op diegene wat op die aarde woon nie (Op. 6:10; Bohren, 1981b:24). Die lyding is nog nie aan sy einde nie. Daar is sprake van 'n lyding in gerig, terwyl die verlede nog so dikwels in die teenwoordige tyd werk; maar daar is ook 'n lyding vanwee die nog-uitstaande-wees van die gerigshandeling van God, 'n lyding daaraan dat die toekoms die hede nog nie kragtig genoeg rig nie. My lyding aan myself en aan die gemeente en aan die wêreld bestaan daarin dat ek nog nie kan sien wat die Gees vir my sê: "Kyk, dit alles het nuut geword" nie (Bohren, 1981b:25).

Pneumatologiese denke ly aan die diskrepans tussen dit wat die gemeente in die Gees is en die praktiese Gees-loosheid van die gemeente. Die lyding van die Christen bestaan ook in die verskil tussen die nuwe wat hy in die Gees is en dit van die ou wese wat nog in hom lewendig is. Pneumatologiese denke weet dat die gerig moet begin by die huis van God (1 Pet. 4:17); dit weet dat die huidige uur van die kerk, die uur van sy gerig is.

Dit is uit die bespreking duidelik dat Bohren se waamemingsbegrip 'n verruimde visie en baie belangrike werkinstrument aan prakties-teologiese arbeid kan bied. Pneumatologiese denke kry nie alleen 'n verruimde visie op die onsigbare (in eskatologiese konteks), sodat daar met nuwe ywer gewerk kan word na die volle realisering van die skone visie nie, maar dit verleen ook - deur lyding heen - 'n kritiese waarnemingskerpte wat die tekens van die tyd kan lees en die krisis-uur waarin die wêreld en die kerk verkeer, kan waameem.

\section{Implikasies van Rudolf Bohren se Pneumatologie vir die Praktiese Teologie}

Dit is nodig om die betekenis van die pneumatologiese insigte van Bohren vir die gereformeerde wetenskapsbeoefening - soos dit in die Praktiese Teologie tot uitdrukking kom - vas te stel. Enkele implikasies van hierdie pneumatologiese insigte word vervolgens aangedui:

\section{- Pneumatologie in trinitariese raamwerk}

Een van die sleutelkenmerke van die teologie van Bohren (waartoe sy trinitariespneumatologiese invalshoek tot 'n groot mate bygedra het) is dat hy teologie nie sien as iets wat afgeslote is, as 'n kenbare grootheid wat reeds deurgrond is nie. 
Wanneer teologie God self reflekteer, sal dit 'n teologie wees wat ons nog nie het nie, wat ons nog eers moet ontdek. In die wording van hierdie teologie word ons veranderend meegevoer in 'n nuwe, nog onbekende in (vgl. 2.1). Hierdie perspektief van Bohren mag waardevol wees vir die benadering tot die Praktiese Teologie in soverre as wat dit die praktiese teoloog kan laat besef dat sy vakgebied nie 'n geslote sisteem is wat deurgrond kan word en wat gevolglik ook op 'n kliniese wyse beheers kan word nie. In die gereformeerde teologie word met 'n sisteem gewerk waarin die Heilige Skrif as vertrekpunt dien vir teoretisering. Waar basisteoretiese omgang met die Skrif die vertrekpunt is vir alle prakties-teologiese arbeid, sal die Skrifbeskouing en Skrifgebruik ook uit die aard van die saak bepaal wat die aard van die teologiebeoefening sal wees.

Hoe kan die teoloog ten opsigte van sy omgang met die Skrif verseker dat hy nie in 'n geslote sisteem vasgevang raak nie? Die gereformeerde praktiese teoloog glo kragtens sy belydenisverbintenis aan die Skrif as geslote kanon en dat alles wat in hierdie lewe nodig is om te weet nog duideliker en meer volkome (as in die algemene openbaring) daarin geopenbaar word (NGB, artikel 2). Die Heilige Skrif bevat die wil van God volkome en alles wat die mens vir sy saligheid moet glo, word daarin voldoende geleer (NGB, artikel 7).

Beteken 'n geslote kanon dat prakties-teologiese teologiebeoefening in 'n geslote sisteem vasgevang sal word - 'n sisteem waaruit die geheimenis en die onkenbare uitgesluit word? Wie 'n eendimensionele beeld van 'n geslote kanon en van die kenbare vorm, kan inderdaad die element van ondeurgrondbaarheid verloor en dit kan tot verarming en gearriveerdheid lei. Maar die Skrif self stel dit duidelik dat die kanon ontsaglike dimensies het sodat die teoloog wat met hierdie aard van die kanon rekening hou, sy teologie nooit in 'n geslote sisteem vasgevang sal laat raak nie. Alhoewel die kanon afgeslote is, is dit oop na bo! Die Skrif self bevestig hierdie ondeurgrondelike wonder van die inhoud daarvan: "Mag julle in staat wees om saam met die gelowiges te begryp hoe wyd en ver en hoog en diep die liefde van Christus strek. Mag julle sy liefde ken, liefde wat ons verstand te bowe gaan, en mag julle heeltemal vervul word met die volheid van God" (Ef. $3: 18,19)$.

Wanneer die praktiese teoloog konsekwent rekening hou met hierdie ondeurgrondelikheid van sy navorsingsveld, sal hy in nederigheid die betreklikheid van sy arbeid besef en sal hy ook nie anders kan as om in wetenskapsvorming nie alleen die taal van prosa te gebruik nie, maar beslis ook om ruimte te skep vir 'n taal wat die aard van poësie dra. Bohren se perspektief kan ook waardevol wees in die sin dat dit die praktiese teoloog behulpsaam kan wees om rekening te hou met dinamiek en beweging in die teologiese denke. Die handelinge in die kerk van die Here word dan nie alleen ondersoek vanuit die invalshoek dat die kerk 'n statiese gegewe is nie, maar ook vanuit die perspektief dat die kerk in 'n eskatologiese beweging op pad na voleinding mooi moet word en dat die aarde 
nuut moet word. Heyns (1990:6) beweeg in hierdie rigting wanneer hy sê: "I see practical theology as concerned with actions that propagate the gospel and promote God's coming to this world".

\section{- Teonome resiprositeit}

Waar dit 'n belangrike taak van die praktiese teologie is om die gemeente deur middel van kritiese monitering en toerusting te begelei deur die wêreld (vgl. Heyns, 1990:13), sou teonome resiprositeit 'n sleutelbegrip kon word in die toerusting van die kerk om die magsgreep van die onbekwame en lekebeeld wat so baie lidmate van hulleself het, te deurbreek. Die gemeente kan sodoende 'n "begabte Gemeinde" (Bohren, 1975:147) word wat nie meer volstrek afhanklik en minderwaardig teenoor ampsdraers staan nie. In hierdie verband sou dit nodig wees dat die praktiese teoloog opnuut weer die implikasie van die belydenisinhoud dat die gelowige mag glo dat die Heilige Gees ook aan hom gegee is (Heidelbergese Kategismus, Sondag 20), moet ondersoek. Die Heilige Gees is nie alleen 'n algemene gawe aan die kerk nie, maar word ook aan elke individuele gelowige gegee, hoe onbelangrik hy homself ook al mag ag.

\section{- Geloof en waarneming}

Dat daar in die eietydse kerkwees so 'n drang is om nuwe dinge te bring wat net op stimulasie van uiterlike sintuie gerig is (vernuwing in liturgie met visuele en aanskoulike elemente - vergelyk kindereredienste, passiespele), bring dalk 'n geestelike oppervlakkigheid aan die lig en wys dat daar nie meer goed besef word dat dit in kerk gaan om dieper kyk, om geloofswaarneming nie. In die geloof kan die hemelse Jerusalem met miljoene engele waargeneem word (vgl. Heb. 12:22). Dit sou nodig wees vir die Praktiese Teologie om opnuut die sursum corda as 'n wesenlike element van praktiese kerkwees te ontdek. Die implikasies van hierdie geloofshandeling van hartsverheffing is verreikend vir 'n verruimde waarnemingshorison - so ruim dat dit tot in die hemele strek! Wat 'n wêreld kan vir die kerk ontsluit word wanneer lidmate leer om in die geloof waar te neem! Waar geestelike blindheid en afstomping (gebrek aan visie) een van die groot probleme van die kerk in sy praktiese kerk-wees kan word, sou 'n helder visie op die onsigbare dinge 'n kragtige motivering kan wees om met nuwe, roepingsbewuste handelinge op te tree in diens van die Here.

\section{Bibliografle}

BAVICK, J.H s.j. Ik geloof in de Heilige Geest (2de druk). Den Haag : Voorhoewe

BERKHOF, H 1964. De leer van de Heilige Geest. Nijkerk : Callenbach.

BOHREN, R 1965. Preaching and community. Richmond : John Knox Press.

BOHREN, R 1967. Predigt als Erzahlung (In Christ, F. red. Oikonomia - Heilsgeschichte als Thema der Theologie. Festschrift O. Cullmann. Hamburg : Herbert Reich Evang. Verlag p. 348-354.) 
BOHREN, R 1975. Daß Gott schon werde - Praktische Theologie als theologische Ästhetik München : Kaiser

BOHREN, R. 1979. Geist und Gericht - Arbeiten zur Praktischen Theologie. Neukirchen : Neukirchener Verlag

BOHREN, R. 1981a. Trost-Predigten Neukirchen-Vluyn : Neukirchener Verlag.

BOHREN, R 1981b Vom heiligen Geist: 5 . Betrachtungen München : Kaiser

BOHREN, R. 1989. Glaube und Ästhetik - ein vergessenes Kapitel der Theologie Berliner Theologische Zeitschrift, 6(1):1-7.

BOHREN, R. 1993. Predigtlehre (6. Auflage). Gütersloh : Gütersloher Verlagshaus

BOHREN, R. 1994. Einfach von Gott reden. Stuttgart : Kohlhammer.

BOHREN, R. 1996. Praktische Theologie als Wissenschaftskritik - Anmerkungen zu Günter Grass: "Über das Sekundare aus primare Sicht". (In Moller, C. \& Ehmann, R, reds. Predigen aus Leidenschaft - Homiletische Beitrăge für Rudolf Bohren zum 75 Geburtstag. Karlsruhe : Verlag Evangelischer Presseverband fur Baden e.V. p. 79-102.)

CALVYN, J. 1976. Calvin's commentaries - The second epistle of Paul the apostle to the Corinthians and the Epistles to Timothy, Titus and Philemon. Grand Rapids : Eerdmans.

CLLIERS, J.H. 1979. Veni Creator Spiritus - 'n homileties-sistematiese besinning oor die belang van die reformatore Karl Barth, Rudolf Bultman en Rudolf Bohren vir die pneumatologies begronde preekleer. Stellenbosch : Universiteit Stellenbosch. (Th.Mverhandeling.)

DAECKE, S.M. 1975. Neue Konjunktur für den Geist - Ungelöste Widersprüche in der Pneumatologie. Evangelische Kommentare, Monatschrift zum Zeitgeschehen in Kirche und Gesellschaft, 8(1):520-523

DAIBER, K 1977. Gundriß der Praktischen Theologie als Handlungswissenschaft - Kritik und Erneuerung der Kirche als Aufgabe. München : Kaiser.

DINGEMANS, G.D J. 1996. Manieren van doen - Inleiding tot de studie van de praktische theologie. Kampen : Kok.

GIANNARAS, A. 1974. Ästhetik heute - sieben Vorträge. München : Francke.

GROZZINGER, A. 1989. Erzählen und Handeln: Studien zu einer trinitarischen Grundlegung der Praktische Theologie. Munchen : Kaiser.

GROZINGER, A. 1995. Praktische Theologie als Kunst der Wahrnehmung Gutersloh Gütersloher Verlagshaus

HASSELMANN, N. 1977. Predigthilfen und Predigtvorbereitung. Gütersloh : Gerd Mohn.

HEITINK, G. 1993. Praktische theologie: geschiedenis - theorie - handelingsvelde. Kampen Kok.

HEYNS, J A 1955. Karl Barth. Wie is hy en wat wil hy? Bloemfontein : Sacum

HEYNS, L M. 1990. Practical Theology is theology. (In Heyns, L.M. \& Pieterse, H.J C. ed. A primer in Practical Theology Pretoria : Gnosis. p. 3-11.)

HEYNS, L.M. \& PIETERSE, H.J.C. 1990. A primer in Practical Theology. Pretoria : Gnosis.

HOENDERDAAL, G J. 1968. Geloven in de Heilige Geest. Wageningen : Veenman

JONKER, W.D. 1981. In diens van die Woord - Enkele opmerkings oor die teologiese gehalte van die amptelike vakke of diakoniologie. Pretoria : NG Kerkboekhandel.

JONKER, W.D. 1983. Die Gees van Christus. Pretoria : NG Kerkboekhandel.

JOOSTE, F.J. 1986. Die relasie tussen die Pneumatologie en die kommunikatiewe dimensies van die verkondigingsgebeure. Pretoria : UNISA. (D Th.-proefskrif.)

JOSUTTIS, M. 1996. Von der gottlichen Dynamik des Evangeliums. (In Möller, C. \& Ehmann, R, reds. Predigen aus Leidenschaft - Homiletische Beitrage fur Rudolf Bohren zum 75. Geburtstag. Karlsruhe : Verlag Evangelischer Presseverband für Baden e.V. p. 10-30.) 
PIETERSE, H.J.C. 1990. Practical Theology as a communicative theological operational science. (In Heyns, L M. \& Pieterse, H.J.C., ed. A primer in Practical Theology Pretoria : Gnosis p. 46-65.)

ROTHERMUNDT, J. 1984. Der Heilige Geist und die Rhetorik. Gütersloh : Gerd Mohn.

SCHULZE, L.F. 1981. Teologie in stroomversnelling. Potchefstroom : PTP

VAN RULER, A.A. 1969. Theologisch werk (Deel 1). Nijkerk : Callenbach

VAN RULER, A.A. 1978. Verwachting en voltooiing - een bundel theologische opstellen en voordrachten. Nijkerk : Callenbach.

VENTER, C.J.H. 1992. Diakoniologie en rasionaliteit - 'n verkenning. In die Skriflig, 26(1):29-51, Maart. 
